\title{
Sentidos produzidos por leitores acerca de suas inscrições no ambiente midiático
}

\author{
Viviane Borelli ${ }^{1}$
}

Resumo: Diversos pesquisadores têm refletido sobre as relações entre mídias e leitores a partir de distintas abordagens teóricas e metodológicas. Nessa reflexão, busca-se identificar que motivações fazem com que os leitores insiram-se no processo de enunciação midiática, bem como interpretar as reflexões que fazem sobre suas relações com os jornais e também sobre os processos interacionais que desenvolvem com outros leitores. No contexto de uma sociedade ainda em vias de midiatização (Verón, 1997), compreende-se que é preciso olhar para os pontos de contato e para as ofertas discursivas que possam alargar ou gerar novos vínculos através daquilo que é colocado em circulação (Braga, 2012). Para entender como ocorrem esses processos interacionais entre jornais e leitores necessita-se observar não só as instâncias da produção e da recepção, mas especialmente para as interpenetrações, as "zonas de contato" (Fausto Neto, 2012). Se outrora os processos enunciativos dependiam em maior grau da mediação das mídias, hoje vive-se um momento em que os sujeitos inscrevem-se em distintos espaços midiáticos através de um protagonismo emergente. Para refletir sobre os motivos que levam leitores a comentarem matérias jornalísticas em sites e páginas de jornais no facebook, foram realizadas entrevistas com leitores dos periódicos portugueses Diário de Notícias e Público e brasileiros Pioneiro e Diário Popular para identificar nessas enunciações marcas, pois, como lembra Verón (2005), "uma superfície discursiva é composta por marcas” (p. 53) que apontem para motivações singulares, o porque da participação nesse locus específico, vínculos que são construídos com os jornais e demais leitores inscritos nessa ambiência midiática.

Palavras-chave: leitor; jornal; midiatização; discurso.

\begin{abstract}
Several researchers have reflected upon the relations between media and readers based on distinct theoretical and methodological approaches. In this reflection, it is aimed to identify which motivations make the readers introduce themselves into the process of mediatic enunciation, as well as interpret the reflections they make about their relations with the newspapers and also about the interactional processes they develop with other readers. In the context of a society still in the process of mediatization (Verón, 1997), it is understood that it is needed to look at the points of contact and the discursive offers that may enlarge or generate new ties through that which is put into circulation (Braga, 2012). In order to understand how these interactional processes between newspapers and readers occur, it is needed to observe not only the instances of production and reception, but specially the interpenetrations, the "contact zones" (Fausto Neto, 2012). If once the enunciative processes depended on a higher level on media mediation, the moment today is about subjects entering distinct mediatic spaces through an emergent protagonism. To reflect upon the reasons why readers comment journalistic reports on newspapers websites and facebook pages, interviews were made with readers of the Portuguese newspapers "Diário de Notícias" and "Público" and of the Brazilian newspapers "Pioneiro" and "Diário Popular" to identify markers in these enunciations, since, as Verón (2005) claims, "a discursive surface is made of markers" (p. 53) that point to singular motivations, the reason for the participation in this specific locus, ties which are built with the newspapers and other readers included in this mediatic ambience.
\end{abstract}

Key-words: reader; newspaper; mediatization; discourse.

\footnotetext{
${ }^{1}$ Universidade Federal de Santa Maria (UFSM/RS). E-mail: borelliviviane@gmail.com. 


\section{Jornais e leitores: relações em permanente construção}

O objetivo do artigo é compreender as motivações de leitores de jornais brasileiros e portugueses para comentarem notícias, inscreverem-se na ambiência midiática e participarem de discussões com outros leitores nos espaços interacionais de sites e páginas no facebook. Para isso, são entrevistados leitores brasileiros e portugueses que comentam matérias e, a partir de suas falas, busca-se identificar marcas discursivas que apontem para intenções de como enunciam-se as estratégias discursivas produzidas para dar visibilidade ao que dizem e como avaliam sua interação com outros que ali também inscrevem-se por meio de enunciações. Utiliza-se o termo inscrição como uma metáfora para designar o ato de enunciação empreendido por um sujeito quando produz um discurso num dado tempo e espaço $^{2}$. A especificidade do estudo repousa sobre um olhar para além do funcionamento dos dispositivos técnicos ou das rotinas jornalísticas, visto que volta-se o olhar também para a instância do reconhecimento, pois são ouvidos leitores para compreender as projeções que fazem sobre suas participações e os motivos que os levam a integrarem quadros enunciativos na ambiência midiática.

Nesse contexto, um dos conceitos caros para esta reflexão é o de contrato de leitura, trabalhado pelo semiólogo argentino Eliseo Verón em diferentes momentos de sua produção acadêmica. "É o contrato de leitura que cria o vínculo entre o suporte e o seu leitor" (Verón, 2005, p. 219), em que o dispositivo de enunciação, para o autor, comporta a imagem de quem fala (relação daquele que fala com o que diz), a imagem daquele a quem o discurso é endereçado (destinatário) e a "relação entre o enunciador e o destinatário, que é proposta no e pelo discurso" (Verón, 2005, p.218).

Nas relações entre jornais e leitores, vínculos poderão ser criados a partir de um processo identitário que se desenrola ao longo de um tempo por meio de contatos. A partir dessa proximidade, pela lógica estrutural do facebook, por exemplo, um portador de uma conta nessa de rede social poderá passar a "curtir" determinada página de um jornal específico e não de outro, tornando-se um "seguidor" e passando a receber as notícias do periódico pelo seu feed de notícias. Esse contrato que cria o vínculo entre os jornais e os leitores pode sofrer

\footnotetext{
${ }^{2}$ Não é intenção avaliar se o que os leitores produzem em termos discursivos é ou pode ser considerado jornalismo, o que já é tratado com propriedade por outros estudos, como os específicos sobre o jornalismo cidadão e participativo. 
mutações, ser quebrado por alguma das partes ou receber reforços e estreitar-se ao longo do tempo.

É no ambiente midiático que os discursos tomam forma por meio de distintas enunciações que acabam instituindo vínculos entre as mídias e os seus públicos específicos. É nesse locus também que ocorrem relações de múltiplas ordens entre os leitores. Porém, mesmo que as enunciações produzidas pelos leitores tenham como lugar específico o ambiente institucional midiático (com normatizações e regramentos permissivos e/ou proibicionistas), em determinados momentos, as interações seguem caminhos próprios porque os discursos circulam constantemente numa cadeia semiótica infinita.

Dessa maneira, outro conceito central é o de circulação aqui compreendido de forma conjugada a outro conceito teórico que tem sido fundamental no decurso de investigações anteriores - o de midiatização. O conceito tem sido formulado a partir de distintas correntes, mas, para fins dessa reflexão, concorda-se com a formulação de Verón (1997), a partir da ideia de que as lógicas e processos midiáticos produzem afetações sobre as práticas das instituições, dos sujeitos e coletivos em relação, havendo um processo crescente de midiatização das sociedades pós-industriais.

Se outrora havia uma suposta linearidade entre produção e recepção - agora há também a emergência da circulação, o que complexifica as relações entre jornais e leitores, pois os sujeitos colocam em pauta uma série de práticas discursivas que remetem ao intercâmbio, à complementaridade de ideias, ao questionamento, à insatisfação e o beneficiamento de informações por parte das produções jornalísticas (Borelli, 2014).

Outro aspecto que resulta do complexo processo de midiatização da sociedade é o controle sobre o processo interacional. Se, antes, os jornais conseguiam estabelecer lugares mais estanques e pontuais (cartas do leitor e artigos de opinião, por exemplo) para a participação, hoje esses espaços são alargados na ambiência da internet e de uma forma singular, os leitores produzem as suas próprias ofertas discursivas, à mercê da regulação dos jornais. Isso pode ser observado tanto a partir da proliferação de produções jornalísticas de caráter coletivo e que fogem ao nomeado jornalismo de referência, bem como por meio de iniciativas mais individualizadas, por meio de blogs e páginas pessoais.

Nesse sentido, mesmo que uma informação produzida inicialmente pela mídia gere enunciações no locus institucional midiático, não há limitações para que permaneça nesse 
ambiente. A lógica da circulação remete a uma infinidade de fluxos possíveis, numa cadeia produtiva ilimitada e difícil de ser mapeada. Diante disso, concorda-se com Braga (2012) quando define a circulação como um espaço "do reconhecimento e dos desvios produzidos pela apropriação" (p.38).

É a partir das problemáticas da incompletude dos sentidos e de uma semiose infinita que Verón $(2005,2013)$ desafia os pesquisadores a compreenderem os sentidos postos em circulação. Ou seja, mesmo que haja a oferta de um determinado discurso no âmbito da produção, não há garantias de que se realize da forma como foi projeto no âmbito do reconhecimento, como lembra Verón (2005), pois há fluxos de múltiplas ordens e não linearidades.

Braga (2012) define que o processo de circulação se concretiza através de fluxos contínuos, difusos e sempre adiante, articulados em distintos circuitos. $\mathrm{O}$ autor também chama a atenção para a geração de contra-fluxos - que seriam respostas produzidas tanto pela instância da produção quanto da recepção. Nesse contexto, precisa-se atentar para o fato de que não são só as mídias que criam discursos e os põem em circulação, visto que os leitores podem iniciar discussões à deriva das mídias e, depois, por injunções de distintas práticas, esses discursos poderão ser construídos também no ambiente midiático. Exemplos são temas discutidos em grupos fechados ou formulados como razão de ser de movimentos sociais que, em dado momento, deixam de ser produzidos nesses ambientes específicos e passam a circular também nas mídias tradicionais.

Trata-se de uma questão que ultrapassa a constatação de que a internet é um meio técnico e segue-se pistas de que há uma certa crise da enunciação jornalística. Essa crise seria um sintoma dessa protagonização dos leitores que produzem sentidos próprios e buscam instituir vínculos não só com aquilo que as mídias dizem, mas também com enunciações produzidas em outros lugares por distintos sujeitos.

Nesse contexto, o facebook, por exemplo, é frequentemente utilizado para ampliar o alcance de determinados conteúdos (Newman, 2009). Porém, compreende-se que esse ambiente midiático específico não pode ser concebido apenas como repositório de notícias ou como um lugar que veicula conteúdos, pois é um espaço interacional singular no âmbito da internet, em que os processos enunciativos desenvolvidos tanto por parte dos jornais quanto dos leitores constroem quadros de enunciação singulares que podem gerar distintos efeitos: 
alargar o contato, possibilitar processos de interação, gerar tensionamentos, discordâncias, entre outros aspectos.

Como conceitua Recuero (2009), o facebook, enquanto um site de rede social propriamente estruturado, possui essa rede expressa por uma lista de amigos/seguidores, bem como uma rede social "realmente viva através das trocas conversacionais dos atores, aquela que a ferramenta auxilia a manter" (Recuero, 2009, p. 103). Quando o usuário acessa o site, a primeira página é constituída de um feed, alimentado pelas atualizações dos contatos e das páginas que o usuário segue. Assim, é nela que também aparecem as notícias publicadas pelos jornais a partir do momento em que os leitores "curtem" as páginas dos periódicos. Dessa forma, quanto mais seguidores conseguirem conquistar no facebook, maior será o número de pessoas vão receber suas atualizações/notícias.

Apresentadas as bases teóricas, é preciso dizer que, do ponto de vista metodológico, foram realizadas entrevistas com leitores dos periódicos portugueses Diário de Notícias e Público e dos brasileiros Pioneiro e Diário Popular ${ }^{3}$ que comentam frequentemente notícias nos espaços possibilitados pelo site e página dos jornais no facebook. As entrevistas foram elaboradas a partir de um roteiro básico de questões (Gil, 2006) que incluiu questões sobre a frequência com que o usuário comentava alguma página do jornal; se costumava ver as notícias diretamente no site do jornal, pelo feed de notícias ou na fanpage do periódico; que tipo de notícias mais chamava a atenção; os motivos que os levava a comentar alguma notícia; como avaliava sua interação com o jornal. Além dessas questões básicas, outras eram realizadas à medida que a entrevista se desenvolvia de uma forma produtiva, visto que

\footnotetext{
${ }^{3}$ Os jornais foram eleitos de forma intencional e integram o corpus de duas pesquisas em desenvolvimento: Produção e circulação da notícia: as interações entre jornais e leitores" (apoio financeiro do $\mathrm{CnPq} / \mathrm{Chamada}$ 43/2013 - Ciências Humanas, Sociais e Sociais Aplicadas) e "A interação entre jornais e leitores nos espaços públicos da internet: uma análise das lógicas, processos e interlocuções que atravessam a enunciação dos media" (Projeto de pesquisa pós-doutoral 2015/2016 realizado na Universidade Nova de Lisboa com bolsa Capes, sob orientação do professor doutor João Pissarra Esteves). O Diário Popular de Pelotas é o mais antigo do Rio Grande do Sul e circula na região Sul desde 1890 (www.diariopopular.com.br). O Pioneiro (www.pioneiro.com.br) é, desde 1948, o principal jornal de Caxias do Sul e pertence à Rede Brasil Sul - Grupo RBS, um dos maiores grupos de comunicação da região Sul do Brasil e que é afiliada às Organizações Globo. Público (www.publico.pt) e Diário de Notícias (www.dn.pt) são dois periódicos portugueses que circulam em Lisboa e região e são tidos como jornais de 'referência' da imprensa portuguesa. Para mais informações sobre os periódicos portugueses, pode-se consultar: Lima, H. \& Reis, A. I. (2014). Mídia noticiosa portuguesa e formas de interatividade em plataformas online. In: Antônio Sardinha, Cláudia Maria Arantes Assis Saar \&, Elaide Martins. (orgs). Convergência midiática e comunicação: cenários, atores e práticas. Macapá: EDUNIFAP.. Sobre os periódicos brasileiros, pode-se consultar Borelli (2014 e 2015).
} 
situações muito diversas ocorreram: alguns entrevistados respondiam todas as questões, mas outros apenas uma ou duas.

Para realizar as entrevistas, utilizou-se como estratégia o contato por meio do facebook, pois, a partir de observações nesse ambiente e no site dos jornais, notou-se que havia uma certa repetição de comentadores. Porém, a incidência de comentários na rede social é muito maior que nos sites, visto que alguns jornais não abrem mais espaço para comentar matérias no site ou, quando o fazem, há limitações de espaço e também uma regulação mais restrita. Para estabelecer um primeiro contato com os leitores, foi criada uma conta na rede social com o nome da autora acrescentado da palavra "pesquisadora" enquadrando, através de um texto introdutório, que o perfil visava uma pesquisa acadêmica. Inicialmente, enviou-se uma mensagem para os primeiros perfis selecionados a partir da observação de nomes de leitores que mais participavam. Porém, deparou-se com uma limitação: como não havia 'amizade' entre a pesquisadora e os leitores na rede social, as mensagens eram enviadas para a pasta 'Outras', que não sinaliza a entrada de nova mensagem e, logo, poderia passar despercebida pelos leitores. Em função disso, avaliou-se que seria necessária outra estratégia de contato pelo pouco retorno das mensagens enviadas: decidiu-se adicionar os leitores, enviando-lhes uma solicitação de amizade. Com o aceite da amizade, as mensagens enviadas seriam direcionadas para o inbox, havendo, assim, mais chances de respostas.

A partir dessas estratégias, conseguiu-se entrevistar 46 pessoas $^{4}$ Para a análise dos dados, os entrevistados (E) serão ordenados numericamente (E1, E2, etc) e referidos diretamente aos jornais dos quais são leitores/comentadores, assim atribuída nomeação: PU (Público), DN (Diário de Notícias), DP (Diário Popular), PI (Pioneiro). As respostas dos entrevistados serão lidas e interpretadas a partir da noção de que todo o discurso deixa marcas na superficialidade textual e que gera um campo possível de efeitos, como pressupõe a análise

\footnotetext{
${ }^{4}$ Avalia-se que houve um retorno razoável se for considerado um total de 120 contatos (entre mensagens enviadas antes do pedido de amizade e/ou após aceite).Entretanto, não há como saber se esses entrevistados representam efetivamente aqueles que mais comentam as matérias desses jornais, pois mesmo que tenham sido escolhidos para envio de pedido de amizade aqueles que mais estavam presentes nesses espaços abertos para comentários, a amostra não pode ser considerada representativa nem do tipo de público que ali participa, nem da proporção de leitores que ali se inscrevem. Porém, como o objetivo da pesquisa não abrange aspectos de ordem quantitativa e independe de outras variantes (faixa etária, gênero, ocupação, situação financeira), os dados servem ao propósito de indicar que fatores motivam a participação e como ela ocorre nesses ambientes. 
semiológica (Verón, 2005). Também serão identificadas singularidades e recorrências nos modos de dizer dos entrevistados que apontem para algumas tendências e explicações acerca do porquê participam dos espaços para comentários nos sites e páginas dos jornais no facebook.

Na sequência, são discutidas algumas abordagens teóricas acerca das relações entre as mídias e seus públicos e que são tensionadas a partir da observação das práticas discursivas dos leitores no ambiente midiático digital, bem como da interpretação das falas dos entrevistados acerca de suas motivações para ali comentarem determinadas notícias. Para além do aporte teórico norteador - e que se centra nos conceitos de midiatização, contrato de leitura e de circulação - , os dados coletados também demandaram um olhar para outros conceitos que são tensionados a partir dos ditos pelos entrevistados e que serão referidos juntamente com a descrição e análise dos dados.

\section{A emergência de outros produtores}

O protagonismo dos sujeitos hoje na ambiência da internet pode ser compreendido a partir de perspectivas que apontam as práticas emergentes por parte dos públicos como resultado da própria configuração descentralizada da web 2.0 (O’Reilly, 2005), pela prática de distintos tipos de jornalismo participativo (Singer et al, 2011), pela propagação de uma cultura da convergência (Jenkins, 2009) ou de uma convergência multimídia, que segundo Erdal (2011), proporciona não só uma cooperação entre as mídias, repercutindo sobre as práticas profissionais e as estratégias organizacionais, mas também sobre os leitores.

Compreende-se que essa produção emergente por parte dos leitores no locus institucional midiático é decorrência de um processo crescente de midiatização das sociedades pós-industriais (Verón, 1997). E é também consequência de um redesenho das próprias ofertas discursivas - não mais produzidas de forma linear (de um produtor para um receptor), mas atravessadas por outras injunções que fazem como o receptor seja re-situado noutra arquitetura comunicacional que o coloca também como coprodutor (Fausto Neto, 2012). Outros aspectos a destacar são, por exemplo, a ampla concorrência no mercado midiático, a perda de leitores por parte dos jornais para outras mídias e mudanças nos hábitos de consumo midiático. 
Assume-se, como perspectiva teórica, o fato de que essa transformação nas ofertas discursivas é um sintoma do processo de midiatização da sociedade. A partir de leitura do esquema analítico da midiatização, proposto por Verón (1997), compreende-se que as relações entre jornais e leitores são não dadas, mas construídas através de interrelações complexas. Nesse contexto, há entrelaçamentos de discursos produzidos não só pelos jornais (mídias) e seus leitores (atores individuais), mas também pelas instituições e os coletivos que se formam a partir dessas relações de distintas ordens. Nesse sentido, não apenas as mídias de grande circulação são afetados pela cultura da convergência e pelo processo de midiatização da sociedade, mas também os pequenos jornais em seus mais diversos estágios de mutação (Borelli, 2015).

A problemática sobre os públicos das mídias é antiga, mas ainda está em curso seja pela sua complexidade ou pelas mutações que os processos midiáticos sofrem ao longo da história. Verón (2006) questiona onde estão os públicos, quem são e como é possível conceitua-los para melhor entendê-los? Para ele, nas últimas décadas, construiu-se uma situação confusa em função dos ajustes realizados pelas pesquisas sobre o fenômeno da recepção. "Estudamos precisamente a recepção de quem para quem? Podemos continuar a falar de receptores, de públicos, de audiências, como se fez durantes anos?” (Verón, 2006, p. 114). A não linearidade do processo de comunicação implica em desafios tanto para quem atua nas mídias, para o mercado publicitário, quanto para quem investiga esses fenômenos, hoje dinamizados com o processo de circulação desses discursos.

A defasagem entre produção e reconhecimento foi objeto de reflexão importante na obra de Eliseo Verón. Na década de 1980, o autor analisou programas de divulgação científica da televisão francesa e entrevistou receptores e profissionais que atuavam na produção ${ }^{5}$. Ao retomar, atualizar e refletir sobre essa pesquisa, Verón (2013) assinala que consiste num erro elaborar um conceito genérico de "público" e que "os receptores estão longe de ser esse público passivo evocado por alguns dos comunicadores" (p. 383). Para ele, mesmo com os limitadores de uma pesquisa pontual, permanecem as questões relativas às modalidades de interpenetrações entre os sistemas individuais e sociais.

\footnotetext{
${ }^{5}$ Estudo semelhante foi realizado nos anos 90 e que é referido em Verón (2013). O autor detalha as lógicas de reconhecimento que foram identificadas em ambos os estudos, fazendo-se comparações entre os discursos que haviam se alterado.
} 
Dayan (2006a) problematiza a questão dos públicos e as mutações que podem ser observadas em distintos contextos e épocas, destacando o caráter transformador dos próprios públicos e, consequentemente, do conceito, pois "os públicos são simultaneamente construções intelectuais e realidades sociais" (p.25). O caráter mutante dos públicos é destacado a partir da ideia de que há uma variação natural ao longo do tempo, em que os públicos têm percursos próprios: "Vão por diferentes etapas, que incluem o nascimento, o crescimento, a fadiga, o envelhecer, a morte e, por vezes, o ressuscitar" (Dayan, 2006a, p. 25). $\mathrm{O}$ autor também levanta a hipótese de que num dado momento os públicos podem tornar-se também “não-públicos” em função dos "destinos que não se realizaram” (Dayan, 2006a, p. 25) e ao buscar, em suas reflexões, a designação para um público específico da televisão, qualifica o seu estatuto como "um quase-público" (Dayan, 2006b, p.47). A reflexão do autor aponta para a complexidade do conceito, as projeções e estudos feitos por teóricos e instituições midiáticas acerca de para quem falam e as problemáticas definições de audiência e público.

Nesse sentido, a problemática das relações entre as mídias e seus públicos perpassa reflexões acadêmicas a partir de distintas abordagens teóricas. Compreender como os leitores se inscrevem nos espaços abertos para participação e que motivações os movem são os objetivos dessa reflexão e não avaliar, stricto senso, os espaços de participação e nem questões de outras ordens, como a regulação, as rotinas produtivas ou a prática jornalística ${ }^{6}$. A seguir, são analisadas as falas dos leitores quanto às questões da interação e participação, refletindo-se sobre os discursos mais recorrentes acerca das motivações, onde possam ser identificadas marcas nas enunciações dos leitores que remetam a um modo específico de estabelecer vínculos com os jornais e demais leitores na ambiência midiática.

\section{Experiência, democracia e lógicas econômicas}

Para além das questões meramente técnicas, uma das possíveis consequências do desenvolvimento tecnológico é o debate público acerca de questões que dizem respeito à

\footnotetext{
${ }^{6}$ Essa abordagem é objeto de outro artigo em processo de elaboração como parte da pesquisa pós-doutoral intitulada "A interação entre jornais e leitores nos espaços públicos da internet: uma análise das lógicas, processos e interlocuções que atravessam a enunciação dos media", que conta com apoio da Capes (bolsa de estágio pós-doutoral) e orientação do professor doutor João Pissara Esteves, da Universidade Nova de Lisboa.
} 
experiência e à própria democracia, esta compreendida como "uma forma de vida" (Esteves, 2011, p.33), que é fundada em valores e normas sociais e que tem como condição de sua existência a participação.

PI-E2 - "Eu acredito que, ao fazer um comentário, eu consigo exercer o meu direito de cidadania";

PI-E18 - "Me posiciono sempre que posso. A interação proporcionada pelo jornal é importante, necessária, saudável, democrática";

DP- E2 - "Participo porque temos que, na minha opinião, expor nossas ideias. Se pagamos impostos então o nosso pensamento tem que estar exposto. Por isso, comento as matérias";

DP- E3 - "Comento as matérias para debater";

DP- E4 - "Comento porque é uma oportunidade de expressar meu pensamento";

DN- E2 - "Tenho sempre muito interesse em ler e participar nas notícias que eu tenho interesse. A maioria das vezes comento por discordar de algumas opiniões;

DN- E4 - "Comento porque é um direito que eu tenho enquanto cidadã de mostrar o meu desagrado ou contentamento";

DN - E6 - "Penso que todos os leitores, quando não estão satisfeitos pela forma que as notícias são veiculadas, deveriam intervir. A isto chama-se Cidadania!"; PU-E1 - "Comento para expressar a minha opinião e também mostrar meu descontentamento em relação a alguns assuntos. Digo mais, que as pessoas na época das redes sociais tentam mais imputar seus ideais nos outros...lol"; PU-E2 - "Acho importante dar a minha opinião e ouvir a dos outros também. É através dum debate de ideias que nos apercebemos de todos os lados das questões e formamos uma opinião mais informada"; PU E4 - "Toda a gente deveria opinar mais e não estruturar a sua vida em ideias feitas ou pré concebidas. Acaba por ser para mim próprio um estímulo a pensar em matérias que no dia a dia não o faria".

Compreende-se que não se pode olhar para as relações entre leitores e mídias a partir de questões estritamente tecnológicas, pois é importante direcionar um olhar para as relações que os sujeitos estabelecem entre si e como se constituem enquanto atores políticos e, portanto, cidadãos. Através do que é enunciado pelos leitores, infere-se que na sua avaliação, o direito de exercer a cidadania (PI-E2; DN- E4; DN- E6) está atrelado diretamente a uma característica essencial da democracia que é a possibilidade de discussão de temas de interesse público na ambiência midiática. O fato de os jornais abrirem espaço para participação é considerado uma ação produtiva para a própria democracia (PI-E18).

A participação em debates proporcionados pela existência desses espaços abertos pelos jornais para comentários é um modo de os indivíduos sentirem-se incluídos na discussão de questões que dizem respeito à ordem da experiência de suas vidas e de seus interesses (DPE4) e, portanto, tem relação com o próprio processo democrático. A abertura de espaço para 
participação é considerada uma oportunidade para discussão de ideias (DP-E3), trocas de opiniões com outros indivíduos e também de mostrar um lado divergente daquilo que é ali dito (DN- E2). Há, singularmente, aqueles que atrelam a necessidade de participação ao fato de ser um contribuinte que paga impostos e, portanto, tem direito a visibilizar o que pensa (DP- E2).

Há, por parte dos jornais, uma série de experimentações em curso acerca da abertura, fechamento e regulação dos espaços de participação. Isso implica não só em mudanças nos modos de fazer do próprio jornalismo (âmbito profissional), mas também numa predefinição do que pode ser dito em determinados ambientes. Como lembra Verón (2005) acerca do contrato de leitura entre as mídias e seus públicos, é possível, por meio da análise semiológica, descrever operações que "determinam a posição do enunciador e, como consequência, a do destinatário" (p. 233). O fato de a interação não ocorrer no locus institucional do jornal (portais e sites oficiais), mas nas redes sociais, representa uma outra lógica discursiva tanto acerca do que é ofertado pelo jornal para ali ser lido, compartilhado e comentado, quanto no próprio desenrolar dos discursos ditos por parte dos leitores. Ou seja, o fato de os jornais postarem notícias em suas páginas no facebook distintas daquelas publicadas nos seus sites denota que é intenção construir diferentes dispositivos de enunciação (Verón, 2005) e, portanto, de quadros enunciativos que projetam leitores singulares.

Nesse contexto, determinados modos de dizer do jornal remetem também ao que poderá ser produzido pelos leitores em termos de expectativas, opiniões e pontos de vista. $\mathrm{O}$ ambiente midiático é outro, portanto, a projeção feita pelos jornais acerca da imagem de seus leitores remete a um dispositivo de enunciação distinto daquele construído nas outras materialidades dos jornais (impresso ou site). Essa lógica distinta não passa despercebida por parte de leitores que possuem uma preconcepção do que seja um site de rede social e as intenções daqueles que nela se inscrevem (PU-E1).

Outro aspecto a ressaltar é que os enunciadores colocam-se no discurso a partir de um “eu” específico, pois, como lembra Rodrigues (2005, p.67), “a primeira pessoa do verbo não se refere a nenhum indivíduo fixo e determinado uma vez por todas, mas à pessoa que a enuncia". Nesse contexto, o que é dito pelos entrevistados delimita um lugar de fala singular, pois a referência ao "eu” é relativa e designa um processo de enunciação que ocorre num dado 
momento. Há dois aspectos a considerar: primeiro, a própria situação da entrevista, em que o enunciador é convidado a responder algo que faz parte de sua experiência pessoal ('por que comenta matérias jornalísticas'); segundo, o convite a uma reflexão sobre ações rotineiras na ambiência midiática, em que a experiência de cada um é acionada para referir aquilo que é de uma ordem singular, de um "eu" demarcado num dado tempo e espaço.

Nesse contexto, as falas dos entrevistados denotam certa modalidade de enunciação que expressa um posicionamento específico da ordem da experiência de cada um, ao mesmo tempo em que referem algo que lhe é exterior (produzir comentários para as páginas dos jornais). Esse aspecto remete a uma característica intrínseca e paradoxal da linguagem, como lembra Rodrigues (2005, p.74), que possui tanto a "função de representar uma realidade exterior e a função de se referir ao próprio facto da enunciação de que é o efeito ou o resultado".

A partir das enunciações construídas pelos leitores, nota-se que há motivações que são da ordem de um "eu" que faz projeções sobre um "outro" e que estão interligadas, visto que todo discurso enunciado por um "eu" projeta um "outro". Os entrevistados enunciam que exercem o direito de posicionar-se e dizer aquilo que pensam (PI-E2: “eu consigo exercer o meu direito de cidadania; DP- E4: "oportunidade de expressar meu pensamento"; P-E1: "expressar a minha opinião"; PU-E2:" dar a minha opinião" ) acerca de determinado tema que lhe chama a atenção e que a ele é atribuído algum valor (DN-E2: "notícias que eu tenho interesse"). Da mesma forma, denotam que inserem-se ainda num ambiente público para discutir, discordar, tensionar o seu posicionamento para travar debates com um "outro" e, por isso, fazem suas próprias projeções sobre o que "outros" deveriam fazer (DN - E6: "Penso que todos os leitores"; PU-E1: "que as pessoas (...) tentam mais imputar seus ideais nos outros"; PU-E2:" ouvir a (opinião) dos outros também"; PU-E4: "Toda a gente deveria opinar mais" ).

O diálogo, a troca de opiniões e a discussão são fatores característicos de uma sociedade democrática e são apontados pelos entrevistados como uma das motivações para enunciarem suas opiniões nesses ambientes. Essas práticas remetem ao que defende Esteves (2011, p. 40) acerca da partilha colaborativa de usuários da internet no que tange à criação de “novas possibilidades de intervenção cívica". Porém, nem sempre essa participação representa efetivamente um amadurecimento ou um grau de discussão cívico dessas questões, visto que, 
muitas vezes, não há efetivamente um debate de ideias e questões éticas ficam à revelia de outros interesses.

\begin{abstract}
PI-E1 - "Os comentários são uma fonte de provocações pessoais, uma verdadeiro cenário de guerra virtual, onde reina a ignorância.... e este não é o meu perfil "verdadeiro""';

PI-E3 - "No Face não comento, porque tem muita bobagem tanto por parte das postagens do jornal quanto dos leitores";

DN E8 - Faço comentários "por piada" (por graça)... gosto de ver as reações... :). Tenho, na minha opinião, que o "jornalismo" de redes sociais é essencialmente de "postar e deitar fora"... curto, pouco fundamentado, apelativo à emoção... mas pouco ou nada informativo ... Poderia escrever alguma reflexão... mas não creio que haja alguém para dar seguimento à conversa... então a coisa curta, humorada, é o que faço...
\end{abstract}

O ambiente destinado pelos jornais para comentários no facebook pode tornar-se um locus de entretenimento, pois há possibilidade de burlar as normas da rede social e criar, por exemplo, um perfil falso, o que favorece o descomprometimento com o que é ali dito (PI-E1). Além disso, alguns leitores avaliam que a rede social não é o local apropriado para construir um debate sério, seja pelos temas das notícias postadas pelos jornais ou pelas opiniões expressas pelos que ali se inscrevem e constroem enunciações que pouco respeitam o outro (PI-E1; PI-E-3; DN-E8). Há a ponderação de que mais vale a pena tornar esse lugar um espaço de entretenimento do que desenvolver estratégias discursivas para produzir um debate produtivo acerca de temas relevantes para a sociedade (DN-E8).

O fato de o espaço destinado pelos jornais para comentários ser um locus singular de trocas de opiniões, não é garantia de pluralismo e nem de que não haja regulações, visto que todos os jornais instituem algum tipo de controle sobre o que pode e deve ser dito nesse ambiente. Além disso, é preciso lembrar que interesses de ordem econômica podem afetar o almejado pluralismo.

PI-E13 - "Caiu muito os conteúdos do jornal..acho que por terem perdido muito nos classificados financeiramente eles focaram mais em vendas do que o restante"; DN- E 1 - "Mais do que dar aquilo que os leitores querem (que é o que geralmente acontece hoje, devido há importância das audiências) que procure dar aquilo que eles precisam;

PU-E5 - "Não! (o jornal não leva em consideração os comentários dos leitores). Penso que só será relevante se puder contribuir para alguma estatística"; 
Os jornais têm passado por transformações em sua prática discursiva para dar conta da concorrência com outras mídias e também para criar novos modos de consumo das informações. Uma das consequências dessa extensão para outros ambientes pode ser não só a diversificação dos conteúdos e formatos, mas também uma mudança de ordem editorial, o que representa, por parte dos jornais a produção de outro tipo de dispositivo de enunciação e, portanto, a projeção da imagem de um outro leitor.

Essas

mudanças não passam despercebidas por parte dos comentadores que avaliam observar uma queda na qualidade do produto oferecido pelos periódicos como consequência de outro cenário, onde imperam apenas os resultados financeiros e os dados quantitativos (PI-E13;DNE1) e que as suas falas só estão nesse ambiente de forma figurativa ou se vierem a integrar alguma estatística quanto ao número de acessos (PU-E5). Na direção dessa perspectiva, recorre-se a Palacios (2010) que sustenta que a emergência de novas práticas jornalísticas que aumentam a participação dos públicos dá-se mais por uma estratégia comercial que visa atrair e manter públicos fidelizados diante da ampla concorrência da indústria jornalística do que capacitar leitores ou considerar suas opiniões nas rotinas de produção.

\section{Considerações sobre processos em mutação}

O fato de os jornais disponibilizarem para seus leitores espaços que permitem a participação não é garantia de que haverá a construção de vínculos, visto que o contato não pressupõe, de antemão, conexões entre os sujeitos. Nesse sentido, avalia-se que o vínculo deve ser entendido como um estágio que vai além de um contato mais indicial e imediato, pois pressupõe uma ligação mais forte e consolidada entre enunciadores. A partir dessa premissa, pode-se diferenciar a prática de leitores que têm uma presença mais frequente nos ambientes midiáticos que permitem participação, por exemplo, daqueles que só visualizam o nome do jornal ou a capa e nem chegam a percorrer os seus enunciados.

No caso dos jornais analisados, notou-se que contratos ali estabelecidos entre leitores e jornais geram vínculos que podem ser fortalecidos a cada edição, mas que também podem ser desestabilizados por não concordância com o tema publicado ou por práticas consideradas não adequadas. Esses tensionamentos, discordâncias e repulsas por parte dos leitores foram identificados por meio de discursos que remetiam à observação de uma mudança de 
abordagem de temas do cotidiano por parte dos jornais ou mesmo por uma ênfase a aspectos de ordem mercadológica em detrimento a um viés jornalístico.

Os leitores também enunciam que reconhecem as diferenças entre os contratos de leitura firmados pelos jornais no ambiente dos sites e no facebook, o que denota que a projeção de determinadas tipologias de públicos encontra algum eco naqueles que ali se inscrevem. Nesse sentido, mesmo que haja dissonâncias entre as instâncias da produção e do reconhecimento, há, em algum momento, pontos de contato que podem ser melhor identificadas com a descrição dos discursos produzidos no ambiente da circulação, hoje mais evidente com o processo de midiatização da sociedade.

Como referido, a pesquisa de caráter qualitativo não possibilita uma abordagem mais macro sobre o tema e nem possibilita comparações mais acabadas entre as falas dos leitores brasileiros e portugueses. Entretanto, por meio de uma análise mais micro e que buscou identificar recorrências, notou-se marcas discursivas que se repetem e predominam em ambos contextos. A primeira diz respeito à percepção de que o espaço de comentários serve para expressão daquilo que se pensa e que é um lugar para expor opiniões individuais e para exercício da cidadania. Ao possibilitar comentários e interações entre os leitores, a mídia se constitui num locus que favorece a participação, o diálogo e a discussão de temas de interesse comum. Porém, a abertura desse espaço não representa, necessariamente, uma maior qualificação do debate de questões de interesse público.

Observou-se que muitas enunciações avaliam esse espaço de forma negativa, ou seja, ao mesmo tempo que os leitores refletem sobre o que pensam acerca da interação no ambiente midiático também fazem projeções do que os outros deveriam fazer e como deveriam agir. Longe de haver convergências, observou-se que esse locus é divergente por natureza, onde imperam discursos que remetem a tensionamentos, a pontos de vista distintos e a interesses de múltiplas ordens. Há, ao mesmo tempo, aqueles que ali se inscrevem para discussão de temas sérios e os que comentam notícias apenas por diversão. Não há, muitas vezes, encadeamento temático acerca do que é dito pelo jornal, o que denota que a enunciação midiática aponta alguns caminhos de leitura que não se concretizam no âmbito do reconhecimento. Esse aspecto aponta para atravessamentos na enunciação midiática, pois se outrora havia uma preponderância sobre o dito, atualmente há falas que provém de outras ordens que não apenas a instância midiática. 
Um último comentário é sobre as lógicas de mercado e as consequências para o jornalismo. Para isso, recorre-se a Wimmer (2010) que aborda a atual fase do jornalismo do ponto de vista financeiro. Para ele, a audiência está nos ambientes digitais e cresce a cada dia, porém não há como monetizar o conteúdo no ambiente digital. Esse fato é um dos desafios enfrentados pelos jornais que produzem informações específicas para postar em suas páginas no facebook, mas que não lucram sobre elas ${ }^{7}$. Pelo contrário, já que uma das lógicas de funcionamento do facebook é justamente oferecer para seus clientes a possibilidade de ampliar o alcance da publicação pagando-se taxas para cada ação específica.

O jornalismo encontra-se numa encruzilhada em que os desafios não são apenas de ordem identitária - quem fala sobre as notícias, quem tem autoridade sobre o dito, como lidar com as enunciações que vêm dos receptores; mas também ética, pois o que é dito pelos leitores integra a enunciação midiática como um todo mesmo que nos termos de participação esteja expresso que o 'jornal não se responsabiliza por conteúdos gerados por outros'. As estratégias utilizadas pelos jornais para trazer para dentro de seu dispositivo de enunciação as falas dos leitores remete mais a um jogo de marketing do que efetivamente à concepção de um outro tipo de jornalismo que se fundamente na participação.

\section{Referências}

Borelli, V. (2015). A circulação da notícia na sociedade em processo de midiatização: o caso de jornais de abrangência regional. Revista Rizoma, vol. 3, n. 1. pp.36-48.

Borelli, V. (2014). Midiatização, circulação da notícia e lógicas de interação entre jornais e leitores In: A. Fausto Neto, N. R. Anselmino \& I.L. Gindin. Relatos de investigaciones sobre mediatizaciones. 1 ed. Rosário, Argentina: UNR Editora- Editorial de la Universidad Nacional de Rosario. pp. 240-254.

Braga, J. L. (2012). Circuitos versus campos sociais. In: J. Janotti Junior, M. A. Mattos \& N. Jacks (Org.). Mediação \& Midiatização. Salvador: EDUFBA; Brasília: Compós.

\footnotetext{
${ }^{7}$ Essa preocupação também perpassa o campo profissional, diante do enxugamento de redações e diminuições na circulação de jornais. Além disso, editores em entrevistas (que serão usadas em outros artigos em construção) mostram sua preocupação diante da imposição do Facebook quanto à cobrança para aumentar o alcance das fanpages.
} 
Dayan, D. (2006a)Dar atenção à atenção: um olhar sobre as audiências e os públicos. In: J. C. Abrantes \& D. Dayan (orgs.). Televisão: das audiências aos públicos. Lisboa: Livros Horizonte.

Dayan, D. (2006b). Televisão, o quase-público. In: J. C. Abrantes \& Dayan, D. (orgs.). Televisão: das audiências aos públicos. Lisboa: Livros Horizonte.

Erdal, I. J. (2011). Coming to Terms with Convergence Journalism: Cross-Media as a Theoretical and Analytical Concept. Convergence: The International Journal of Research into New Media Technologies. 17(2). pp. 213-223.

Esteves, J. P. (2011). Novos Media e Deliberação: Sobre Redes, Tecnologia, Informação E Comunicação. Media \& Jornalismo, N..$^{\circ}$ 18, Vol. ${ }^{\circ}$ 10, N. ${ }^{\circ}$ 1. pp. 31-45.

Fausto Neto, A. (2012). Narratividades jornalísticas no ambiente da circulação. In: F. Piccinin,; D de A. Soster. (Org.). Narrativas comunicacionais complexificadas. Santa Cruz do Sul: EDUNISC.

Gil, A. C. (2006). Métodos e técnicas de pesquisa social. São Paulo: Atlas.

Jenkins, Henry (2009). Cultura da Convergência. São Paulo: Aleph.

Newman, N. (2009). The rise of social media and its impact on mainstream journalism: a study of how newspaper and broadcasters in the UK and US are responding to a wave of participatory social media, and a historic shift in control towards individual consumers. Oxford: Reuters Institute for the Study of Journalism,. Disponível em: http://pt.slideshare.net/nuevaterra/the-rise-of-social-media-and-its-impact-on-mainstreamjournalism-15840746. Acesso em 15 nov. 2014.

Palacios, M. (2010). Putting yet another idea under the Glocalization Umbrella: Reader Participation and Audience Communities as market strategies in globalized online journalism. Communicatio. South african journal for communication theory and research. Volume 36 (2). Recuero, R. (2009). Redes Sociais na Internet. Porto Alegre: Sulina.

Rodrigues, A. D. (2005). A partitura invisivel: para uma abordagem interactiva da linguagem. Lisboa: Edições Colibri.

Singer, J; B. Hermida, A. Domingo, D. Heinonen, A.Paulussen, S. Quandt, T... Vuhnovic, M. (2011). Participatory Journalism: Guarding Open Gates at Online Newspapers. [s.i]: WileyBlackwell. 
Verón, E. (2006). Os públicos entre produção e recepção: problemas para una teoria do reconhecimento. In: J. C. Abrantes \& D. Dayan (orgs.). Televisão: das audiências aos públicos. Lisboa: Livros Horizonte.

Verón, E. (1997). Esquema para el análisis de la mediatización. Revista Diálogos de la Comunicación, n.48, Lima: Felafacs.

Verón, E (2005). Fragmentos de um tecido. São Leopoldo: UNISINOS.

Verón, E. (2013). La Semiosis Social 2: Ideas, momentos, interpretantes. $1^{\circ}$ ed. Ciudad Autónoma de Buenos Aires: Paidós.

Wimmer, K. (2010). Digital Journalism: The Audience Is Here. But Who's Monetizing the content?, The Media Institute. Disponível em http://www.mediainstitute.

org/PDFs/Policy-Views-5-Wimmer-6-8-10.pdf. Acesso em 20 nov. 2015. 